\title{
Seismic stratigraphy and sedimentary architecture of the Chalk Group in south-west Denmark
}

\author{
Connie Larsen, Jon Ineson and Lars Ole Boldreel
}

The Chalk Group is ubiquitous in the subsurface of the Danish Basin and its upper levels are exposed locally onshore, most notably in eastern Denmark. Although many subsurface studies have been made of the group in the Danish Basin, most of these have been in the eastern part of Denmark (e.g. Esmerode et al. 2007; Surlyk \& Lykke-Andersen 2007) whereas the stratigraphy and character of the Chalk Group in the western onshore region is less well-known. The work described here was undertaken as a BSc project at the Department of Geosciences and Natural Resource Mangement at the University of Copenhagen by the first author as part of regional seismic mapping work contributing to an evaluation of the geothermal energy potential in Denmark. The aim of this paper is to present a summary of the key results of the study. We have subdivided and mapped the distribution of the Chalk Group in the northern North German Basin and the south-western Danish Basin based on digital reflection seismic profiles. We also highlight seismic architectural features that testify to periods of active bottom currents.

\section{Geological setting}

Following rifting in Late Carboniferous - Early Permian times, the Mesozoic history of the Danish Basin was dominated by thermal subsidence, albeit with an important midJurassic uplift event and phases of localised inversion in the Late Cretaceous - Palaeogene (Liboriussen et al. 1987). The combination of high sea-levels, a peneplaned hinterland and aridity in northern Europe in the Late Cretaceous led to a reduced influx of siliciclastic sediment to the sea and favoured the accumulation of pure pelagic chalk composed primarily of skeletal fragments from coccolithophorid algae. The pelagic chalk deposits were subject to redistribution by various processes including downslope mass-flow movements from
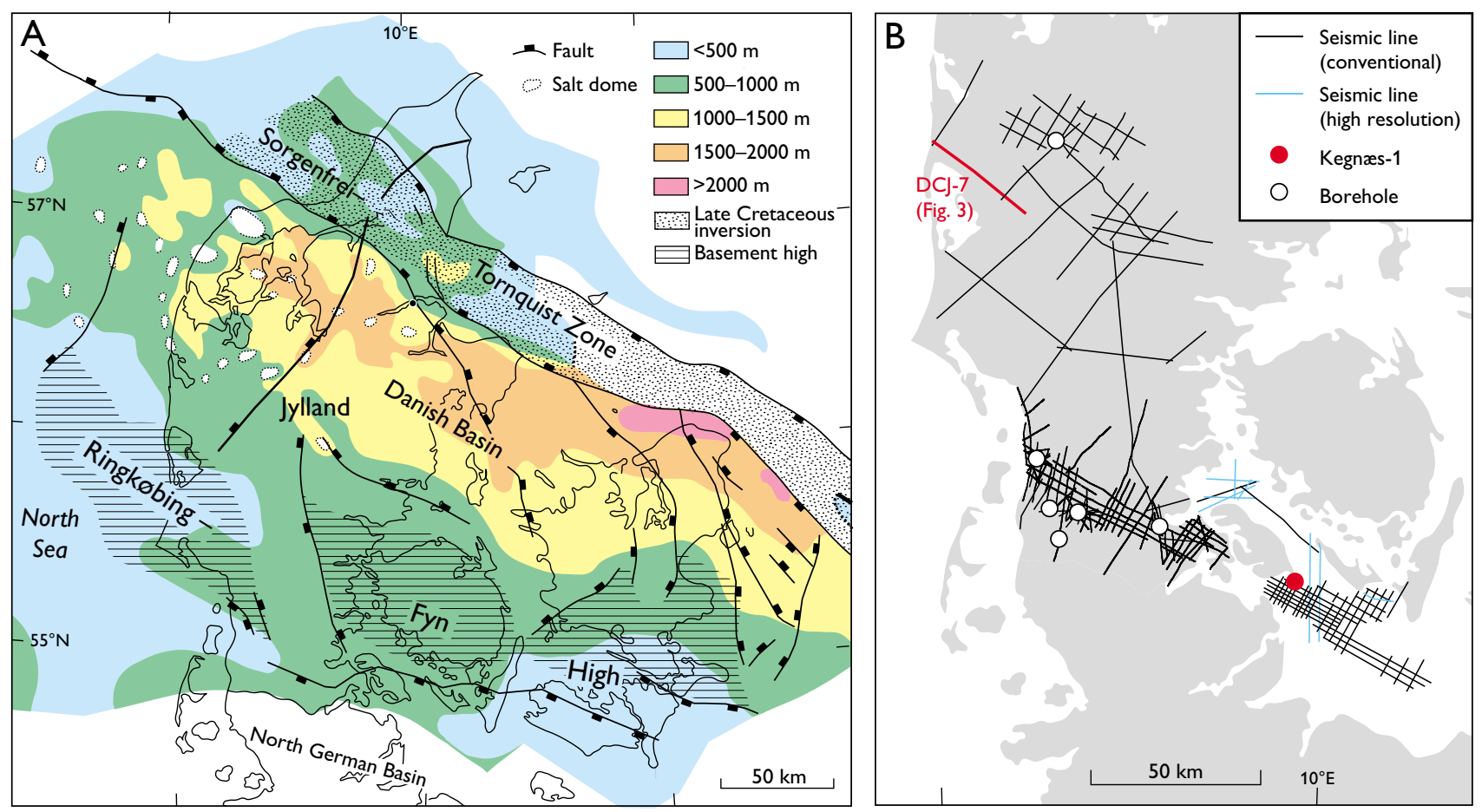

Fig. 1. Structural map of the Danish Basin (A) showing the thickness of the Upper Cretaceous - Danian Chalk Group (modified after Rasmussen \& Surlyk 2012); note that the study area (shown in detail in B) straddles a major structural high, the Ringkøbing-Fyn High. The enlarged map (B) displays the seismic lines and deep boreholes used in this study; highlighted in red are the Kegnæs-1 borehole (see Fig. 2) and the seismic line illustrated in Fig. 3. 
slope instability caused by syndepositional tectonics as well as along-slope bottom currents that sculpted the sea floor into valleys, channels, drifts, ridges and mounds (e.g. Surlyk \& Lykke-Andersen 2007).

\section{Results}

The subdivision of the Chalk Group is based on seismic facies analysis and seismic structural analysis, and the resultant seismic units are correlated to wireline-logs and stratigraphic units from seven deep boreholes (Fig. 1). The study used 2D digital and scanned seismic profiles from nine surveys onand offshore; the digital high-resolution and conventional offshore data are of high quality whereas onshore the digital data are of good quality and the few older scanned data are of low quality. The interval between the base and top of the Chalk Group on the seismic profiles is divided into seismic units based on the recognition and mapping of relatively strong, bounding reflectors. The brief descriptions of the units given below are based on the interpretation of all the seismic profiles in the study area. In the northern part of the study area, the Chalk Group is subdivided into 10 seismic units but the uppermost unit is absent south of the Ringkøbing-Fyn High, i.e. only nine units are recognised in this area (Figs 1,2). The inferred ages of these units are based on correlation to dated borehole sections.

Seismic units 1-3 show parallel, continuous or discontinuous reflector patterns with low amplitude. Boundaries of unit 1 are clearly defined on gamma-ray logs (Fig. 2) whereas the boundaries of unit 3 are typically marked by minor log fluctuations. Units 1-3 are recognised throughout the study area and are broadly of Cenomanian, Turonian and Coniacian ages respectively.

Seismic units 4-6 display discontinuous, semi-parallel internal reflector patterns which are locally chaotic. Boundaries can be correlated with minor gamma-ray log fluctuations in most boreholes; the base of unit 6 is marked by a prominent sonic peak $\log$ in the Kegnæs-1 borehole (Fig. 2). Units 4-6 are recognised throughout the study area and are of probable Santonian, early Campanian and late Campanian ages respectively.

Seismic units 7 and 8 show discontinuous, semi-parallel internal reflector patterns that become chaotic locally. Correlation to log data in boreholes can be difficult but a clear response is observed on the gamma-ray logs in some of the boreholes; the unit is recognised throughout the study area and probably of early to mid-Maastrichtian age.
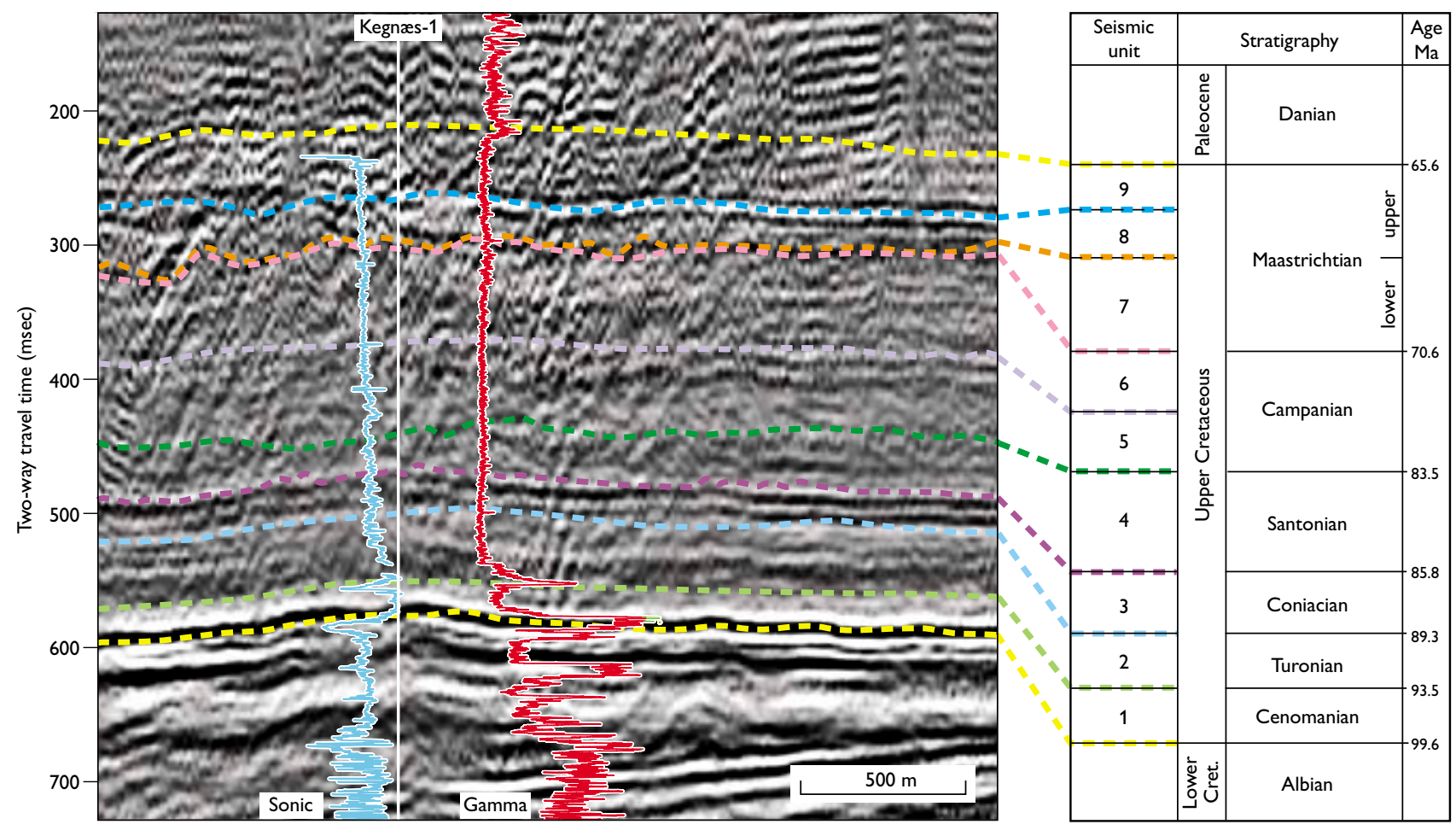

Fig. 2. Seismic profile (in two-way travel-time, TWT) intersecting the Kegnæs-1 borehole, illustrated by the sonic log (blue) and gamma-ray log (red), and showing the correlation between the seismic units and the chronostratigraphy, based on data from Gearhart (1986). 


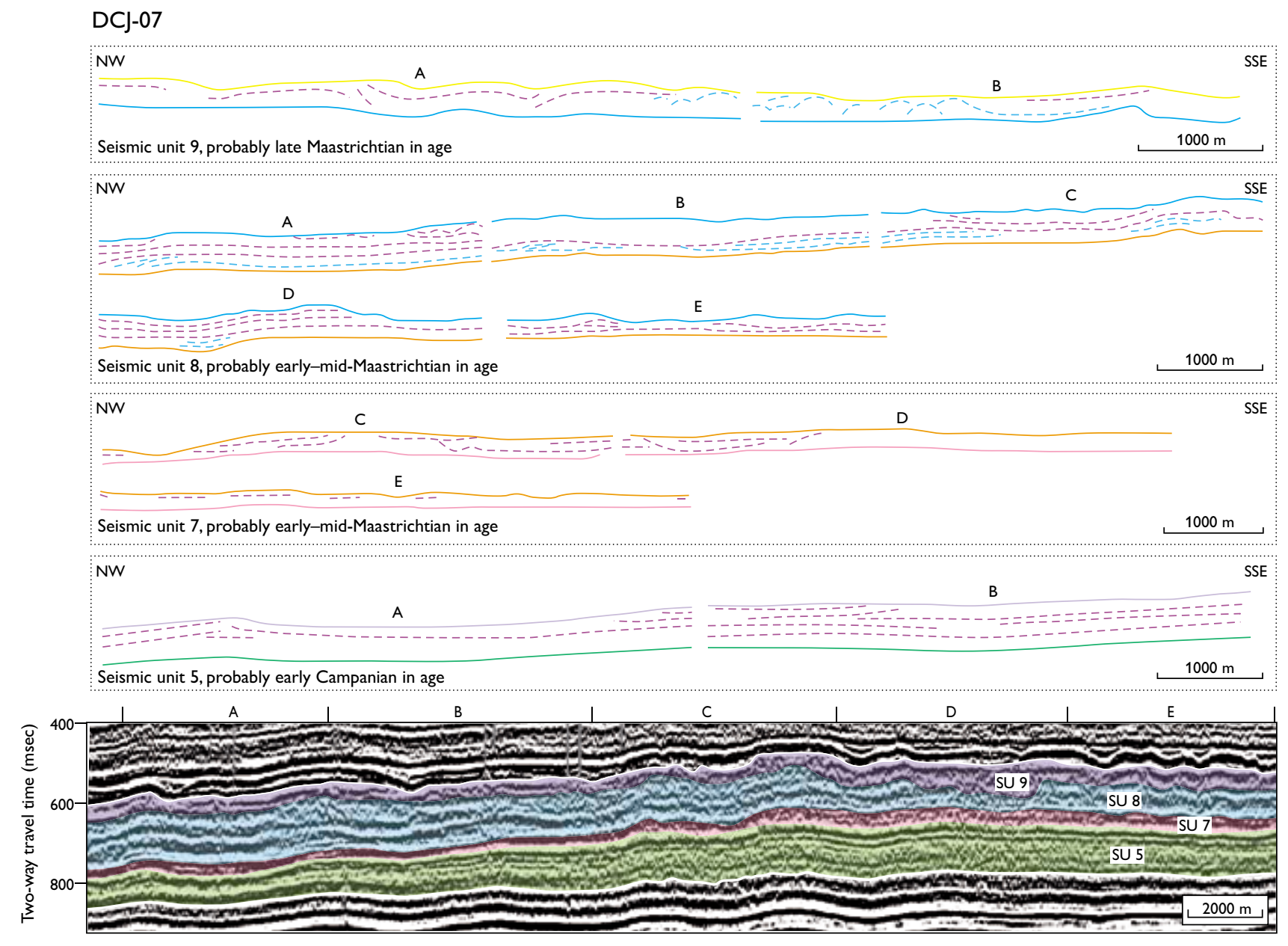

Fig. 3. Internal architecture of selected seismic units in the seismic profile DCJ-07 (for location, see Fig. 1): unit 5 (green), unit 7 (pink), unit 8 (blue) and unit 9 (purple). The accompanying sketches illustrate the internal architecture of these units; the bounding surfaces indicated in colour are defined on Fig. 2 .

Seismic unit 9 commonly shows localised disturbance of the internal reflector pattern but elsewhere exhibits a parallel, continuous to discontinuous pattern. The unit boundaries are readily correlated to gamma-ray logs and are recognised throughout the study area. Unit 9 is of probable late Maastrichtian age.

Seismic unit 10 is only present in the western part of the study area, north of the Ringkøbing-Fyn High, and wedges out to the south near the Ringkøbing-Fyn High. It shows a parallel, continuous or discontinuous internal reflector pattern with high amplitude. It is recognisable on some of the gamma-ray logs and is probably of early Danian age.

Based on seismic facies analysis, seismic units $1-3$ and 9 (Cenomanian, Turonian, Coniacian and upper Maastrichtian ages respectively) typically display parallel and low-angle, mounded internal geometries, whereas seismic units 4-8 (Santonian, Campanian, lower Maastrichtian) show low- angle, mounded, sigmoidal, oblique and hummocky forms (Fig. 3). Evidence of seismic truncation, linked in some cases to $\log$ or biostratigraphic data, indicates the presence of three unconformities in the upper Chalk Group at 'mid-Campanian' (base unit 6), 'Base Maastrichtian' (base unit 7) and 'Top Maastrichtian' (top unit 9, base unit 10 where present); these surfaces seem to be associated with complex systems of major drift, minor mounded drift and channel-like features (Fig. 3).

\section{Discussion}

Mapping the distribution and thickness of the Chalk Group seismic units in the study area illustrates both regional trends, related to active inversion of the Sorgenfrei-Tornquist Zone during deposition of the Chalk Group, and local trends related to the influence of the Ringkøbing-Fyn High. The structural control exerted by Late Cretaceous inversion along the Sorgenfrei-Tornquist Zone is reflected by the over- 
all geometry of the Chalk Group and the gentle northward tilt of the base of the Chalk Group (see also Lykke-Andersen \& Surlyk 2004).

The influence of the Ringkøbing-Fyn High, at least episodically, is indicated by both the distribution of the Danian strata and by the evidence of active bottom current activity. The Danian chalk succession (seismic unit 10) is limited to the area north of the Ringkøbing-Fyn High and locally these deposits are preserved in trough-like, channel features. This distribution is consistent with the work of Thomsen (1995) who reported that the Danian succession wedges out in the south-western part of Jylland, crossing the Ringkøbing-Fyn High. Major drifts, minor mounded drifts and channel-like features are identified north of the Ringkøbing-Fyn High and represent a complex depositional system that is mainly recognised in the Campanian-Maastrichtian interval; such features were not identified south of the Ringkøbing-Fyn High. Most of the structures are recognised on NW-SEand NNW-SSE-oriented seismic lines indicating, together with internal architecture, drift migration towards the NW or NNW. A comparable, complex system has been described in the Øresund area (Esmerode et al. 2007; Surlyk \& LykkeAndersen 2007) where it is seen in middle Santonian - Campanian and upper Maastrichtian intervals, and is considered to be analogous to modern deep-water contourite systems; i.e. that the deposits were moulded by bottom currents that flowed parallel to bathymetric contours. Such processes do not seem to have influenced the Santonian succession in the study area of south-west Denmark, possibly because there was no significant bathymetric relief in this part of the basin at that time.

In addition to the upper surface of the Chalk Group south of the Ringkøbing-Fyn High, two intra-Chalk unconformities are recognised seismically over the entire study area, the inferred mid-Campanian hiatus and the 'Base Maastrichtian' surface; note that the former is correlated to a pronounced cemented layer (hardground?) and a biostratigraphically defined middle Campanian hiatus in the Kegnæs-1 borehole (Gearhart 1986). According to Abramovitz et al. (2010), two major unconformities are recognised within the Chalk Group in the southern part of the Danish Central Graben: one within the Turonian-Campanian Hod Formation and one at the base of the overlying Maastrichtian Tor Formation boundary. Although it is possible that the 'intra-Hod' unconformity may correspond in part to the
mid-Campanian hiatus in Jylland, this event in the Danish Central Graben has typically been attributed a Santonian age (e.g. Abramovitz et al. 2010). It is noteworthy, however that a mid-Campanian inversion event is well-known from the Central Graben in the Netherlands sector (van der Molen et al. 2005). The 'base-Tor' unconformity of the Danish Central Graben may correspond to the Base Maastrichtian unconformity recognised in this study. Future work will focus on tying the Jylland data set with that of the betterstudied Chalk Group of eastern Denmark.

\section{Acknowledgements}

The regional investigations to assess the geothermal energy potential in Denmark are supported by the Danish Agency for Science, Technology and Innovation, and INTERREG4A (European Regional Development Fund).

\section{References}

Abramovitz, T., Andersen, C., Jacobsen, F.C., Kristensen, L. \& Sheldon, E. 2010: 3D seismic mapping and porosity variation of intra-chalk units in the southern Danish North Sea. In: Vining, B.A. \& Pickering, S.C. (eds): Petroleum geology: from mature basins to new frontiers 1, 537548. London: Geological Society.

Esmerode, E.V., Lykke-Andersen, H. \& Surlyk, F. 2007: Ridge and valley systems in the Upper Cretaceous chalk of the Danish Basin: contourites in an epeiric sea. In: Viana, A.R. \& Rebesco, M. (eds): Economic and palaeoceanographic significance of contourite deposits. Geological Society Special Publication (London) 276, 265-282.

Gearhart 1986: Biostratigraphy report. Texaco 5410/5-1 Danish well [Kegnæs-1], 33 pp. Unpublished report, Gearhart Geo Consultants Ltd. (In archives of GEUS - File 9689).

Liboriussen, J., Ashton, P. \& Tygesen, T. 1987: The tectonic evolution of the Fennoscandian border zone in Denmark. Tectonophysics 137, 21-29.

Lykke-Andersen, H., \& Surlyk, F. 2004: The Cretaceous-Palaeogene boundary at Stevns Klint, Denmark: inversion tectonics or sea-floor topography? Journal of the Geological Society (London) 161, 343-352. Rasmussen, S.L. \& Surlyk, F. 2012: Facies and ichnology of an Upper Cretaceous chalk contourite drift complex, eastern Denmark, and the validity of contourite facies models. Journal of the Geological Society (London) 169, 435-447.

Surlyk, F. \& Lykke-Andersen, H. 2007: Contourite drifts, moats and channels in the Upper Cretaceous chalk of the Danish Basin. Sedimentology 54, 405-422.

Thomsen, E. 1995: Kalk og kridt i den danske undergrund. In: Nielsen, O.B. (ed.): Danmarks geologi fra kridt til i dag, 31-67. Århus: Geologisk Institut, Aarhus Universitet.

Van der Molen, A.S., Dudok van Heel, H.W. \& Wong, T.E. 2005: The influence of tectonic regime on chalk deposition: examples of the sedimentary development and 3D-seismic stratigraphy of the Chalk Group in the Netherlands offshore. Basin Research 17, 63-81.

\footnotetext{
Authors'addresses

C.L. \& L.O.B., Department of Geosciences and Natural Resource Mangement, University of Copenhagen, Øster Voldgade 10, DK-1350 Copenhagen K, Denmark.E-mail:gnk171@alumni.ku.dk

J.I., Geological Survey of Denmark and Greenland, Øster Voldgade 10, DK-1350 Copenhagen K, Denmark.
} 